\title{
PENGARUH DESENTRALISASI FISKAL, SISTEM PENGENDALIAN INTERNAL DAN KINERJA PEMERINTAH DAERAH TERHADAP AKUNTABILITAS LAPORAN KEUANGAN
}

\author{
Heppy Purbasari ${ }^{I}$ \\ * Fakultas Ekonomi dan Bisnis, Uninversitas Muhammadiyah Surakarta \\ *heppy.purbasari@ums.ac.id ${ }^{1}$ \\ Andy Dwi Bayu Bawono ${ }^{2}$ \\ * Fakultas Ekonomi dan Bisnis, Uninversitas Muhammadiyah Surakarta \\ *andy.bawono@ums.ac.id ${ }^{2}$
}

\begin{abstract}
This research aims to examine an impact of fiscal decentralization, internal control system, and local government performance examination to the local government financial accountability. As Local autonomy implemented in Indonesia in 1999, it has impacted to several financial reform in Indonesia such as fiscal decentralization calculation, new model of internal control system, new criteria of local government performance and also local financial report accountability. This study collected secondary data from Badan Pemeriksa Keuangan Republik Indonesia by using 117 local government in Java Island as population. The study used purposive sampling method that consists of 106 local government that were analyzed by linear regression by using SPSS 21. The result showed that internal control system has significant impact to the local government financial accountability. However, fiscal decentralisation and local government performance examination has no significant influence to local government financial accountability.
\end{abstract}

Keywords: decentralisation fiscal, internal control system, local government performance, local government financial accountability.

\section{Pendahuluan}

Konsep New Public Management (NPM) merupakan konsep yang digunakan di Negara-negara maju seperti Eropa dan Amerika, yang saat ini sudah merebak implementasinya di Negara-negara Asia seperti Indonesia, Korea Selatan, Thailand dan Malaysia. Penggunaan konsep NPM berawal dari penilaian bahwa organisasi sector public sering mengalami kerugian, berkualitas rendah, kurang memiliki inovasi dan kreatifitas, serta kurang efisien dan efektif. Secara khusus NPM dapat juga dilakukan untuk mengukur tingkat kepuasan masyarakat atas pelayanan yang diberikan pemerintah. Di era tahun 1980-an dan 1990-an penerapan NPM diberagai negara salah satunya menekankan pada pelaksanaan modernisasi pemberian pelayanan public, devolusi dan desentralisasi (Bawono, 2015).

Desentralisasi di Indonesia di mulai pada tahun 2001 yang kemudian pelaksanaannya dengan penyempurnaan tatanan politik pemerintahan terhadap UU No. 22 tahun 1999 diganti dengan UU No. 32 tahun 2004 tentang pemerintah daerah dan UU No. 25 tahun 1999 yang diganti dengan UU No.
33 tahun 2004 tentang sumber pendapatan daerah. Penyempurnaan ini kemudian diikuti dengan adanya otonomi daerah sebagai berlakunya desentralisasi fiscal (Mujiati \& Purbasari, 2014)

Liu (2007) menyatakan desentralisasi fiscal merupakan fungsi pengeluaran belanja dan sumber pendapatan dari Pemerintah Daerah, hal itu menjadi tren di pemerintahan untuk memperbaiki dan mengembangkan Negara maupun dalam transisi ekonomi. Pemberlakuan desentralisasi fiscal berarti mengharuskan Pemerintah Daerah untuk dapat mengurusi daerahnya dengan mengalokasikan belanja yang sesuai dengan pendapatannya, yang berarti pemerintah daerah dapat menggali potensipotensi sumber daya yang berada di wilayahnya. Berdasarkan UU No 32 Tahun 2004 tentang Pemerintah Daerah, Desentralisasi merupakan penyerahan wewenang pemerintah pusat kepada pemerintah daerah otonom untuk mengatur dan mengurus urusan pemerintahan dalam sistem Negara Kesatuan Republik Indonesia.

PP No 8 Tahun 2006 tentang Pelaporan Keuangan dan Kinerja Instansi Pemerintah menjelaskan Sistem pengendalian Intern (SPI) di 
sektor pemerintahan merupakan suatu proses yang dipengaruhi oleh manajemen yang diciptakan untuk memberikan keyakinan yang memadai dalam pencapaian efektivitas, efisiensi, ketaatan terhadap peraturan perundang-perundangan yang berlaku dan keandalan penyajian laporan keuangan pemerintah. Hasil laporan BPK tahun 2013 terhadap Laporan Keuangan Pemerintah Daerah (LKPD) dengan opini BPK TMP dan TW terjadi karena terdapat kelemahan SPI, yang rata-rata terjadi pada system pengendalian akuntansi, system pengendalian pelaksana anggaran pendapatan dan belanja dan pada struktur pengendalian intern.

Dalam siaran pers BPK RI dalam pemeriksaan keuangan pada Semester II Tahun 2013 dilakukan atas LKPD (Laporan Keuangan Pemerintah Daerah) Tahun 2012 pada 108 Pemerintah Daerah meliputi 7 Laporan Keuangan (LK) Pemerintah Provinsi, 88 LK Pemerintah Kabupaten, dan 13 LK pemerintah Kota. Selain itu, BPK juga melakukan pemeriksaan atas 9 LK Badan lainnya. Terhadap 108 LKPD Tahun 2012, BPK memberikan opini WTP (Wajar Tanpa Pengecualian) atas 7 LKPD, opini WDP (Wajar Dengan Pengecualian) atas 52 LKPD, opini TW (Tidak Wajar) atas 2 LKPD, dan opini TMP (Tidak Memberikan Pendapat) atas 47 LKPD. Sedangkan pada badan lainnya, BPK memberikan opini WTP atas 2 LK, WDP atas $1 \mathrm{LK}$, dan TMP atas 6 LK. Adapun permasalahan-permasalahan atas LKPD Tahun 2012 yang tidak memperoleh opini WTP antara lain adalah adanya pembatasan lingkup pemeriksaan, aset tetap yang belum dilakukan inventarisasi dan penilaian, penatausahaan kas yang tidak sesuai dengan ketentuan, kelemahan pengelolaan yang material pada akun aset tetap, kas, piutang, persediaan, investasi permanen dan non permanen, aset lainnya, belanja pegawai, belanja barang dan jasa, serta belanja modal. Siaran pers BPK menyatakan bahwa dalam memberikan opini, BPK mengacu pada beberapa hal yaitu kesesuai dengan Standar Pokok Pemerintah (SAP), kecukupan pengungkapan, kepatuhan terhadap perundangundangan dan kepatuhan terhadap SPI.

Ketika otonomi daerah mulai diterapkan oleh Pemerintah Republik Indonesia mulai muncul masalah yaitu salah satunya rendahnya transparansi dan akuntabilitas laporan keuangan pemerintah daerah. Menurut BPK masalah tersebut muncul karena rendahnya kuantitas dan kualitas sumber daya manusia di bidang keuangan dan pengawasan di daerah dalam menerapkan Standar Akuntansi Pemerintah (Mulyani dan Suryawati, 2011).

Berdasarkan penjelasan sebelumnya dapat diambil kesimpulan bahwa dengan adanya otonomi daerah maka pemerintah daerah dituntut untuk dapat mandiri untuk mengurusi pemerintahannya sendiri dan dalam pelaksanaannya pemerintahan harus menjalankan sesuai peraturan yang telah ditetapkan agar dapat memperoleh kinerja yang baik sehingga akuntabilitas laporan keuangan dapat diterima dengan Wajar Tanpa Pengecualian.

Lebih lanjut, berdasarkan laporan BPK tahun 2012 diketahui masih banyaknya LKPD yang memililiki opini TMP. Untuk itu, peneliti tertarik untuk melakukan penelitian bagaimanakah Pengaruh Desentralisasi Fiskal, Sistem Pengendalian Internal dan Kinerja Pemerintah Daerah Terhadap Akuntabilitas Laporan Keuangan di Pemerintah Kabupaten/Kota di Pulau Jawa pada tahun 2014. Penelitian ini merupakan gabungan antara penelitian Herawati (2014) dan Fontanella dan Rossieta (2014). Perbedaan penelitian ini dengan penelitian sebelumnya belum adanya peneliti yang menggabungkan penelitian tentang pengaruh Desentralisasi Fiskal, SPI dan Kinerja Pemerintah Daerah dengan Akuntabilitas Laporan Keuangan Pemerintah Daerah. Sehingga tujuan dari penelitian ini adalah untuk menganalisis lebih mendalam mengenai Desentralisasi Fiskal, Sistem Pengendalian Internal dan Kinerja Pemerintah Daerah dapat mempengaruhi Akuntabilitas Laporan Keuangan Pemerintah Daerah.

\section{Kajian Pustaka dan Pengembangan Hipotesis \\ a. Desentralisasi Fiskal dan Akuntabilitas Laporan Keuangan \\ Penelitian tentang desentralisasi fiskal sudah} banyak diteliti antara lain oleh Bawono (2015), Mujiati dan Purbasari (2015), Liu (2007), Mimba (2007). Bawono (2015) menyatakan awal desentralisasi fiskal di Indonesia di mulai dengan berlakunya UU No 22 tahun 1999 tentang Pemerintah Daerah dan UU No 25 tahun 1999 tentang Perimbangan Keuangan Pusat dan Daerah yang menjadi tonggak awal proses desentralisasi di Indonesia. Lebih lanjut Bawono (2015) 
mengemukakan bahwa UU diatas memberikan perubahan yang sangat fundamental untuk pemerintah daerah dengan melibatkan transfer pertanggungjawaban dan keuangan dari pusat ke daerah.

Mujiati dan Purbasari (2015) menyatakan bahwa sebelumnya pemerintah Indonesia menganut sistem pemerintahan yang sentralistik dimana dengan sistem pemerintahan tersebut pemerintah daerah tidak dapat berperan aktif dalam pengembangan daerahnya. Dengan adanya kendala tersebut kemudian pemerintah menginisiasi untuk menerapkan otonomi daerah dengan harapan pemerintah daerah dapat mengembangkan daerahnya karena pemerintah daerah lebih memahami hal-hal yang dibutuhkan oleh daerahnya dan dapat memanfaatkan potensi daerahnya untuk meningkatkan pendapatan asli daerah.

Dalam rangka pelaksanaan otonomi daerah, daerah dituntut untuk dapat memberikan informasi kepada stakeholder, maka pemerintah perlu memiliki standar akuntansi keuangan pemerintah daerah yang memadai, walaupun lingkungan akuntansi pemerintah daerah sangat komplek, tetapi hal inilah yang menjadi tantangan pemerintah untuk dapat menerapkan sistem akuntansi (Mardiasmo, 2009). Untuk mewujudkan keinginan stakeholder mengenai informasi pemerintah daerah diperlukan pengembangan dan penerapan sistem pertanggungjawaban yang jelas, nyata dan tepat sasaran sehingga penyelenggaraan pemerintah dan pembangunan dapat berlangsung secara baik, bersih, bertanggung jawab dan terbebas dari KKN (Sedarmanti, 2012).

Bahkan Mimba, et al (2007) mengemukakan bahwa desentralisasi menjadi tren baru dihampir semua negara berkembang, dan desentralisasi khususnya fiskal menjadi elemen yang sangat penting dalam reformasi sektor publik di negara berkembang. Akan tetapi, organisasi sektor publik di negara berkembang menghadapi kondisi yang tidak seimbang diantara permintaan dan penawaran atas informasi kinerja.

Fontanella dan Rossieta (2014) menemukan bahwa Desentralisasi Fiskal dalam bentuk Tingkat Kemandirian Daerah dan Kinerja penyelenggaraan pemerintah berpengaruh positif terhadap kemungkinan tingginya Akuntabilitas pelaporan keuangan pemerintah daerah. Mudhohar dan Tahar
(2016) menyatakan kemandirian daerah berpengaruh positif terhadap laporan keuangan, karena dengan kemandirian daerah yang tinggi sehingga dapat membiayai belanja daerah dengan mandiri sehingga daerah dapat memberikan pertanggungjawaban, melaporkan dan mengungkapkan segala aktivitasnya. Berdasarkan uraian yang telah disebutkan maka dirumuskan hipotesis pertama adalah sebagai berikut: $\mathrm{H}_{1}$ : Desentralisasi Fiskal Berpengaruh Terhadap Akuntabilitas Laporan Keungan Pemerintah Daerah

\section{b. Sistem Pengendalian Intern dan Kualitas Laporan Keuangan}

Mulyati et al (2011) menganalisis salah saji akuntansi berdasarkan SPI di Kabupaten Bojonegoro memiliki tanggung jawab untuk mengatur dan menyelenggarakan pengendalian terkait dengan catatan keuangan, memberikan keyakinan bahwa laporan keuangan telah sesuai dengan SAP, dan memberikan keyakinan yang memadai terkait dengan keamanan aset yang berdampak material terhadap laporan keuangan. Dari laporan LHP selama 3 tahun berturut-turut dari tahun 2007-2009 menunjukkan bahwa kelemahan SPI dari tahun ke tahun semakin berkurang yang pada tahun 2007 terdapat 10 kelemahan SPI dan bersifat material dan sampai pada tahun 2009 hanya terdapat 6 kelemahan SPI dan bersifat tidak material karena terjadi kesalahan pencatatan yang tidak disengaja.

Sari (2012) mengemukakan bahwa dari hasil perhitungan Pengendalian Intern yang terdiri dari keandalan laporan keuangan, efektifitas dan efisiensi kegiatan operasional, pengamanan aset negara dan kepatuhan terhadap peraturan perundang-undangan, dan hasil perhitungan dari Transparasi Laporan Keuangan yang diproxykan dengan kemudahan dalam mengakses informasi keuangan, pengungkapan hal-hal yang bersifat material, pengungkapan secara berkala dan kesesuaian dengan peraturan yang berlaku, kabupaten Cimahi memiliki kategori yang baik dengan masing masing variabel mendapatkan nilai $80 \%$ dan $81,3 \%$. Setelah di uji secara statistik diperoleh hasil bahwa terdapat hubungan yang signifikan antara pengendalian internal dengan transparansi laporan keuangan yang berarti semakin baik pengendalian internal di Kabupaten Cimahi maka transparansi laporan keuangan juga semakin tinggi. Berdasarkan uraian diatas, peneliti merumuskan hipotesis ke-2 sebagai berikut: 
$\mathrm{H}_{2}$ : Sistem Pengendalian Intern berpengaruh terhadap Akuntabilitas Laporan Keuangan

\section{c. Kinerja Pemerintah Daerah dan Akuntabilitas Laporan Kauangan}

Halim dan Kusufi (2012) menyatakan sistem pengukuran kinerja sektor publik adalah sistem yang memiliki tujuan membantu manajer dalam menilai capaian strategi dengan tolak ukur kinerja keuangan dan non keuangan. Lebih lanjut pengukuran kinerja sektor publik di dunia telah berkembang pesat sejak dirintis di Amerika Serikat sekitar tahun 1940-an. Perkembangan tersebut kemudian menyebar keseluruh negara di dunia melalui pengaruh programprogram dari organisasi international seperti PBB, World Bank, dan IMF (Bawono, 2015)

Di beberapa negara berkembang terjadi peningkatan kebutuhan untuk pengukuran kinerja dan informasi kinerja, akan tetapi dikarenakan kapasitas institusi yang rendah dan level korupsi yang tinggi, peningkatan kebutuhan tersebut tidak selalu diikuti dengan kecukupan supply dari informasi kinerja yang memunculkan posisi kebutuhan tidak terpuaskan (Mimba, et al, 2007).

Di Indonesia, perkembangan pengukuran kinerja dimulai dengan pemberlakukan Inpres No 7 tahun 1999 tentang LAKIP (Laporan Akuntabilitas Kinerja Instansi Pemerintahan) yang dalam perkembangannya memunculkan juga penilaian kinerja lain berupa LPPD (Laporan Penyelenggaraan Pemerintah Daerah) dan LKPJ (Laporan Keterangan Pertanggungjawaban). Perkembangan pengukuran kinerja ini memberikan peluang kepada daerah untuk membuktikan diri sebagai daerah terbaik di Indonesia (Bawono, 2015).

Fontanelle dan Rossieta (2014), konsisten dengan penelitiannya Lin (2010) yang menyatakan bahwa kinerja pemerintah daerah memiliki hubungan yang positif dengan akuntabilitas laporan keuangan, sehingga semakin baik opini kinerja yang diberikan maka semakin tinggi kemungkinannya daerah tersebut memiliki akuntabilitas laporan keuangan yang tinggi. Berdasarkan uraian diatas, peneliti merumuskan hipotesis ketiga sebagai berikut:

$\mathrm{H}_{3}$ : Kinerja Pemerintah Daerah Terhadap Akuntabilitas Laporan Keuangan

\section{Metode Penelitian}

Penelitian ini menggunakan populasi pada Pemerintah Kabupaten/Kota yang berada di Pulau Jawa. Sedangkan sampel yang digunakan adalah Pemerintah Kabupaten/Kota yang berada di Pulau Jawa. Kriteria pengambilan sampel adalah Pemerintah Kabupaten Kota yang memiliki Laporan Hasil Pemeriksanaan (LHP) dari BPK.

Data yang digunakan dalam penelitian ini adalah data sekunder yang langsung diperoleh dari LHP. Analisis data yang digunakan dalam penelitian ini adalah Analisis Regresi Berganda dimana sebelumnya dilakukan pengujian asumsi klasik terlebih dahulu.

$$
\text { Akun }=\alpha+b_{1} D F+b_{2} S P I+b_{3} \text { Kinerja }+\square
$$

Keterangan:

$$
\begin{array}{ll}
\text { Akun } & =\text { Akuntabilitas Laporan Keuangan } \\
\text { DF } & =\text { Desentralisasi Fiskal } \\
\text { SPI } & =\text { Temuan Sistem Pengendalian Intern } \\
\text { Kinerja } & =\text { Kinerja Pemerintah Daerah }
\end{array}
$$

Penelitian ini memiliki dua variabel yaitu variabel independen yang terdiri dari Desentralisasi Fiskal yang diproxykan dengan kemandirian daerah, Sistem Pengendalian Intern yang diproxykan dengan jumlah temuan SPI dan Kinerja Pemerintah Daerah yang dikategorikan dengan Sangat Tinggi memiliki nilai 5, Tinggi memiliki nilai 4 , Sedang memiliki nilai 3, Rendah memiliki nilai 2 dan Sangat Rendah memiliki nilai 1 . Sedangkan variabel dependen yang digunakan adalah Akuntabilitas Laporan Keuangan yang diproxykan dengan opini dari BPK. Pengukuran opini dari BPK dikategorikan sebagai berikut: TMP dengan nilai 1 , TW dengan nilai 2 , WDP dengan nilai 3, WTPDPP dengan nilai 4 dan WTP dengan nilai 5.

\section{Hasil dan Pembahasan}

Populasi dalam penelitian ini terdiri dari Pemerintah Kabupaten/Kota yang berada di Pulau Jawa pada tahun 2014. Total populasi sebesar 117 Pemerintah Kabupaten/Kota, dengan menggunakan purposive sampling dengan kriteria kesediaan data opini dari LHP BPK, maka data yang dapat dijadikan sampel sebesar 109 Pemerintah Kabupaten/Kota. Sedangkan data yang dapat diolah sebesar 107 Pemerintah Kabupaten/Kota dikarenakan dua sample tidak lengkap.

Deskriptif dari penelitian ini dapat diketahui bahwa yang memiliki tingkat Desentralisasi paling tinggi terdapat di Provinsi DKI Jakarta dan yang 
memiliki Desentralisasi paling rendah terdapat di

\begin{tabular}{clccc}
\hline Ket & \multicolumn{1}{c}{ Uji CLT } & $\begin{array}{c}\text { Uji } \\
\text { Park }\end{array}$ & VIF & Tolerance \\
\hline DF & $\begin{array}{l}\text { Karena jumlah } \\
\text { sampel sudah > } 30\end{array}$ & 0,320 & 0,712 & 1,405 \\
SPI & $\begin{array}{l}\text { maka dat dalam } \\
\text { penelitian ini } \\
\text { diasumsikan } \\
\text { kerdistibusi normal }\end{array}$ & 0,063 & 0,730 & 1,370 \\
& & 0,947 & 1,056 \\
\end{tabular}

Kabupaten Pangandaran. DKI Jakarta memiliki Desentralisasi Fiskal tinggi karena banyaknya aktivitas ekonomi yang dilakukan di sana sehingga menambah pendapatan asli daerah Provinsi DKI Jakarta. Dari 107 sampel yang masih mempunyai temuan SPI paling banyak terdapat di Provinsi DKI Jakarta yaitu terdapat 32 temuan, sedangkan yang memiliki temuan paling rendah terdapat di Kota Kediri dan Kabupaten Boyolali dengan jumlah masing-masing 2 temuan. Banyaknya temuan yang terjadi di Provinsi DKI Jakarta rata-rata terdapat pada pendapatan pajak, baik pajak kendaraan bermotor, bea balik nama, pendapatan bea perolehan hak atas tanah dan bangunan dan masih banyak yang lainnya. Dari 107 sampel yang memiliki Kinerja Pemerintah Daerah dengan kategori Sangat tinggi terdapat 69 Pemerintah Kabupaten/Kota sedangkan sisanya sejumlah 38 Pemerintah Kabupaten/Kota memiliki kategori Kinerja yang tinggi, sehingga dapat disimpulkan bahwa Kinerja Pemerintah Daerah di Pemerintah Kabupaten/Kota di Pulau Jawa lebih dari $50 \%$ memiliki kinerja yang sangat baik. Selain itu dari sampel 107 yang memiliki opini WTP sejumlah 60 Pemerintah Kabupaten/Kota, sedangkan yang memiliki opini WTPDPP sejumlah 45 Pemerintah Kabupaten/Kota dan yang memiliki opini TMP sejumlah 2 Pemerintah Kabupaten/Kota yaitu di Kabupaten Subang dan Provinsi Banten. Dengan semakin sedikitnya opini TMP maka dapat disimpulkan bahwa akuntabilitas Pemerintah Kabupaten/Kota di Pulau Jawa semakin membaik.

Data penelitian ini diolah dengan menggunakan SPSS versi 21. Alat analisis yang digunakan adalah Regresi Berganda. Sebelum dilakukan analisis Regresi Berganda, peneliti menganalisis asumsi klasik yang terdiri dari Normalitas, Heterokedatisitas, dan Multikolinearitas. Hasil pengujian asumsi klasi adalah sebagai berikut:
Tabel 4.1

\section{Sumber data diolah}

Pengujian Asumsi Klasik

Berdasarkan tabel tersebut data dalam peneliti ini telah terbebas dari masalah asumsi klasik. Sehingga dapat dilanjutkan untuk pengujian regresi.

\section{Pengujian Regresi Berganda}

Tabel 4.2

Pengujian Regresi Berganda

\begin{tabular}{ccc}
\hline Ket & T hitung & Sign \\
\hline DF & 1,538 & 0,127 \\
SPI & $-4,337$ & 0,000 \\
KPD & 1,514 & 0,133
\end{tabular}

F hitung $=7,739 \quad$ sign $=0,000$

Adj R Square $=0,160$

Sumber data diolah

Berdasarkan tabel tersebut dapat diketahui bahwa model penelitian ini adalah Fit karena memiliki sign ( $p$-value) 0,000 dan $\mathrm{F}$ hitung 7,739 yang lebih besar dari $\mathrm{F}$ Tabel 3,08 sehingga dapat diartikan bahwa model penelitian ini dapat dilanjutkan. Jika dilihat dari Adjusted $\mathrm{r}$ Square sebesar 0,160 atau $16 \%$ yang berarti variabel Desentralisasi Fiskal, Sistem Pengendalian Intern, dan Kinerja Pemerintah Daerah dapat menjelaskan variabel Akuntabilitas Laporan Keuangan sebesar $16 \%$ sedangkan $84 \%$ dapat dijelaskan oleh variabel lain, misalnya pengelolaan keuangan daerah, kualitas laporan keuangan, pemeriksaan dan pengawasan laporan keuangan, dan sebagainya.

Pengaruh Desentralisasi Fiskal terhadap Akuntabilitas Laporan Keuangan

Variabel Desentralisasi Fiskal dalam penelitian ini menggunakan proxy kemandirian daerah dari sisi pendapatan. Dari hasil pengujian analisis regresi berganda diketahui bahwa Desentralisasi Fiskal tidak berpengaruh terhadap Akuntabilitas Laporan Keuangan, dengan sign ( $p$ value) sebesar $0,127>\alpha(0,05)$ dan berarti $\mathrm{H}_{1}$ (Desentralisasi Fiskal berpengaruh terhadap Akuntabilitas Laporan Keuangan) ditolak, sehingga dapat disimpulkan bahwa yang menyatakan bahwa 
Desentralisasi Fiskal tidak berpengaruh secara signifikan terhadap Akuntabilitas Laporan Keuangan. Hal ini dapat terjadi karena Pemerintah Kabupaten/Kota yang berada di Pulau Jawa sebagian besar belum bisa mengembangkan PAD sehingga masih memiliki ketegantungan dengan pemerintah pusat, dan mengakibatkan Pemerintah Kabupaten/Kota merasa tidak memiliki tanggung jawab dalam melaporkan kegiatan yang berkaitan dengan PAD, sehingga Pemerintah Kabupaten/Kota tidak mementingkan Akuntabilitas Laporan Keuangan dari sisi Desentralisasi Fiskal. Hal ini tidak sesuai dengan penelitiannya Fontanella dan Rossieta (2014), Nurhidayati (2017), yang menyatakan bahwa Desentralisasi Fiskal memiliki pengaruh positif terhadap Akuntabilitas Laporan Keuangan.

Pengaruh Sistem Pengendalian Intern terhadap Akuntabilitas Laporan Keuangan

Pengujian atas variabel temuan Sistem Pengendalian Intern terhadap Akuntabilitas Laporan Keuangan memiliki hasil yang berpengaruh secara negatif signifikan, dengan sign $000<\alpha(0,05)$ sehingga $\mathrm{H}_{2}$ diterima yang menyatakan bahwa Sistem Pengendalian Intern berpengaruh terhadap Akuntabilitas Laporan Keuangan, yang berarti semakin sedikit temuan SPI yang didapat maka Akuntabilitas Laporan Keuangan semakin baik. Berdasarkan data yang diolah Pemerintah Kabupaten/Kota telah memenuhi standar yang telah ditetapkan oleh UU No 60 tahun 2008. Hal ini sesuai dengan penelitian Ramon (2014) yang menyatakan bahwa variabel sistem pengendalian internal dapat meningkatkan akuntabilitas laporan keuangan pada Inspektorat Kota se Provinsi Sumatera Barat, dengan $\mathrm{t}$ hitung 9,618 yang lebih besar dari $\mathrm{t}$ tabel sebesar 1,670 .

\section{Pengaruh Kinerja Pemerintah Daerah terhadap Akuntabilitas Laporan Keuangan}

Dari hasil pengujian regresi berganda diperoleh hasil bahwa Kinerja Pemerintah Daerah tidak berpengaruh terhadap Akuntabilitas Laporan keuangan, karena memiliki sign $0,133>\alpha(0,05)$ sehingga $\mathrm{H}_{3}$ ditolak yang menyatakan bahwa Kinerja Pemerintah Daerah berpengaruh terhadap Akuntabilitas Laporan Keuangan. Hal ini berarti dalam pemberian opini BPK tidak hanya melihat dari hasil evaluasi kinerja penyelenggaraan pemerintah daerah terhadap laporan penyelenggaraan pemerintah daerah, tetapi juga berdasarkan LKPJ dan LAKIP.
Dan hasil penelitin ini berbanding terbalik dengan penelitiannya Fontanelle dan Rossieta (2014), yang konsisten dengan penelitiannya Lin (2010) yang menyatakan bahwa kinerja pemerintah daerah memiliki hubungan yang positif dengan akuntabilitas laporan keuangan, sehingga semakin baik opini kinerja yang diberikan maka semakin tinggi kemungkinannya daerah tersebut memiliki akuntabilitas laporan keuangan yang tinggi.

\section{Simpulan}

Berdasarkan hasil temuan dalam penelitian ini, memiliki hasil yg menarik karena penelitian ini menghasilkan bahwa:

1. Variabel Desentralisasi Fiskal tidak berpengaruh terhadap Akuntabilitas Laporan Keuangan pada Pemerintah Kabupaten/Kota yang berada di Pulau Jawa, karena memiliki nilai $\mathrm{t}$ hitung sebesar 1,538 dengan sign $0,127>\alpha$. Hal ini membuktikan bahwa besar kecilnya proporsi PAD terhadap pendapatan daerah tidak berpengaruh terhadap akuntabilitas, disebabkan akuntabilitas suatu pemerintah daerah lebih dipengaruhi oleh temuan SPI dan variabel lainnya semisal leadership pimpinan di daerah.

2. Variabel Sistem Pengendalian Intern berpengaruh signifikan secara negatif terhadap Akuntabilitas Laporan Keuangan pada Pemerintah Kabupaten/Kota yang berada di Pulau Jawa, karena memiliki t hitung sebesar 4,337 dengan sign $0,000<\alpha$. Hal ini membuktikan bahwa dengan sistem SPI yang baik, akan membuat akuntabilitas pemerintah daerah semakin baik

3. Variabel Kinerja Pemerintah Daerah tidak berpengaruh secara signifikan terhadap Akuntabilitas Laporan Keuangan pada Pemerintah Kabupaten/Kota yang berada di Pulau Jawa, karena memiliki t hitung sebesar 1,514 dengan sign $0,133>\alpha$. Dalam hal ini, kinerja pemerintah daerah terbukti tidak berpengaruh terhadap akuntabilitas, hal ini disebabkan karena elemen pengukuran kinerja di pemerintah daerah tidak terkait dengan akuntabilitas laporan keuangan.

\section{Saran}

Dari penelitian ini mempunyai beberapa kendala, diharapkan penelitian berikutnya untuk: 
1. Menambahkan variabel independen, variabel intervening atau variabel moderating untuk mengetahui faktor-faktor yang mempengaruhi Akuntabilitas Laporan Keuangan di Pemerintah Kabupaten/Kota

2. Menambahkan Kabupaten/Kota yang lainnya yang berada di Indonesia

Jika menambahkan Kabupaten/Kota di seluruh Indonesia diharapkan tidak menggunakan time serries supaya tidak terkena pengujian Autokorelasi.

\section{Referensi}

[1] Bawono, A. D. B. (2015). The role of performance based budgeting in the Indonesian public sector (Doctoral dissertation, Department of Accounting and Corporate Governance, Faculty of Business and Economics, Macquarie University).

[2] Fontanella, Amy dan Hilda Rossieta. 2014. Pengaruh Desentralisasi Fiskal dan Kinerja terhadap Akuntabilitas Laporan Keuangan Pemerintah Daerah di Indonesia. SNA 17 Mataram. Lombok.

[3] Halim, Abdul. Syam Kusufi. 2012. Akuntansi Sektor Publik Dari Anggaran Hingga Laporan Keuangan Dari Pemerintah Hingga Tempat Ibadah. Salemba Empat. Jakarta

[4] Herawati, Tuti. 2014. Pengaruh Sistem Pengendalian Intern Terhadap Kualitas Laporan Keuangan (Survei Pada Organisasi Perangkat Daerah Pemda Cianjur). Study \& Accounting Research Vol. XI, No. 1, ISSN 1693-4482

[5] Lin, Ming-lan., Lee, Yuan-Duen., Ho, TsaiNeng. (2010). Applying integrated EA/AHPto evaluate the economic performance of local governments in China. EuropeanJournal of Operational Research, 209 (2011) 129-140.

[6] Liu, Chih hung (2007). What Type of Fiscal Decentralization System has better Performance. School of Public Policy

[7] Laporan tahunan BPK RI. 2013

[8] Mardiasmo. 2009. Akuntansi Sektor Publik. Andy Offset. Yogyakarta

[9] Mujiati dan Heppy Purbasari. 2015. Pengaruh Desentralisasi Fiskal terhadap Angka Melek
Huruf dan Angka Partisipasi Sekolah di Kabupaten/Kota Provinsi Jawa Tengah Periode 2010-2011. FEB UMS. Surakarta

[10] Mimba et al. 2007. Public Sector Performance Measurement in Developing Countries. Journal of Accounting \& Organizational Charge Vol. 3 No. 3, 2007 pp 192-208. Emerald Group Publishing Limited 1832-5912.

[11] Mudhofar, Kurniatun dan Afrizal Tahar. 2016. Pengaruh Desentralisasi Fiskal dan Kinerja Terhadap Akuntabilitas Pelaporan Keuangan Pemerintah Daerah Di Indonesia: Efek Moderasi dari Kinerja. Jurnal Akuntansi dan Investasi, Vol. 17 No. 2, Hlm: 176-185.

[12] Mulyani et al. 2011. Analisis Peran dan Fungsi Sistem Pengendalian Intern Pemerintah (SPIP/PP No.60 Tahun 2008) Dalam Meminimalisasi Tingkat Salah Saji Pencatatan Akuntansi Keuangan Pemerintah Daerah. Jurnal Organisasi dan Manajemen, Vol. 7 No. 2 pp 102-116.

[13] Nurhidayati, Sri. 2017. Pengaruh Desentralisasi Fiskal , Kinerja Penyelenggaraan Pemerintah Daerah dan Tindak Lanjut Rekomendasi Hasil Pemeriksaan BPK Terhadap Opini Laporan Keuangan Pemerintah Daerah di Indonesia. Bandar Lampung.

[14] Ramon, Dolly. 2014. Pengaruh Sistem Pengendalian Intern Terhadap Akuntabilitas Laporan Keuangan (Studi Empiris Pada Inspektorat Kota Se Provinsi Sumatera Barat. Jurnal Akuntansi No. 2 Vol. 2.

[15] Sedarmayanti, 2012, Good Governance Kepemerintahan Yang Baik.Bagian Pertama, Edisi Revisi: Mandar Maju, Bandung.

[16] Sari, Diana. 2012. Pengaruh Pengendalian Internal Terhadap Transparansi Laporan Keuangan Pemerintah Daerah. Proceedings ISSN-2252-3936. Bandung,

[17] Peraturan Pemerintah No. 8 Tahun 2006 tentang Pelaporan Keuangan dan Kinerja Instansi Pemerintah

[18] Undang-Undang No 32 tahun 2004 tentang Pemerintah Daerah

[19] www.bpk.go.id 